\author{
Anna Lewicka-Strzałecka \\ Polish Academy of Sciences \\ Institute of Philosophy and Sociology \\ e-mail: alewicka@ifispan.waw.pl
}

\title{
Ethical model of lobbying: An analysis of the codes regulating lobbying activity*
}

\begin{abstract}
Self-regulation initiatives are undertaken by many lobbying circles in various countries. The key element of those initiatives are codes of ethics including a postulated model of lobbying activities, a specific pattern of ethical standards of lobbying. The aim of the article is a reconstruction of this pattern on the basis of the analysis of eight codes representing American, Polish, British, European and German lobbying.

The analysis leads to the following conclusions. An axiological base of the lobbyist profession is created by such values as honesty, reliability, integrity, trust, professionalism, civic responsibility, openness, transparency, loyalty, respect, courtesy. Norms included in the codes are concentrated on the following issues: legality, transparency of actions, care of reputation and dignity of the profession, avoiding corruption, conflict of interest, customer relationship, duties toward society, public relations. A weak element of lobbying self-regulation is a system of norm execution.
\end{abstract}

Keywords: lobbying, code of ethics, self-regulation

JEL Classification: D72

\footnotetext{
* The article is an updated version of the paper published in Polish in the Annales. Ethics in Economic Life, 15, 109-119.
} 


\section{Introduction}

Self-regulatory initiatives are undertaken by many lobbying groups in various countries, including the Association of Professional Lobbyists in Poland. The key elements of these initiatives are ethical codes containing a postulated lobbying model, a specific pattern of ethical lobbying standards. The aim of the article is to reconstruct this pattern based on an analysis of the eight codes representing American, Polish, British, European and German lobbying:

(1) Principles for the Ethical Conduct of Lobbying - a draft code developed by Woodstock Theological Center (2002);

(2) Code of Professional Ethics of the Association of Professional Lobbyists in Poland (Jasiecki, Molęda-Zdziech \& Kurczewska, 2006);

(3) Code of Conduct-The Association of Professional Political Consultants (the largest association of British consulting companies);

(4) Code of Ethics - The American League of Lobbyists (American association of professional lobbyists);

(5) Code of Conduct-The Society of European Affairs Professionals (a European association of lobbyists based in Brussels);

(6) Code of Conduct-CLAN Public Affairs (one of the largest lobbying companies based in Brussels);

(7) Code of Conduct for Interest Representatives-European Commission;

(8) Code of Conduct - German Association of Political Consultants (a German association of consultants operating in the field of politics).

The numbers assigned to particular codes will be used for a short reference to them in the following analyzes.

\section{Code form}

All codes considered, except one (1), regulating the lobbying activity, have a rather concise form, limited to the formulation of several-a dozen or so principles, generally covering one page. They differ fundamentally from professional codes of the profession with established tradition, such as the code of ethics of a doctor, or codes of legal professions. The clerical nature of the codes proves that the profession of a lobbyist has a not yet fully formed identity. Many activities carried out by lobbyists can be attributed to other professions, as illustrated by the fact that some people and companies avoid this term. The conciseness of the codes is naturally related to the relatively high level of generality of the standards contained in it. The slightly larger volume of the Code (1) than the others shows a certain direction of extending the ethics of lobbying activities. It rather depends on adding certain general rules and repeating them in a slightly different, more complex style than on the formulation of more specific standards of conduct. 
Most of the codes have an introductory part - the preamble, in which the addressees of the code, the lobbying mission in contemporary society, and the basic values are generally defined. Codes (1) and (4) are targeted at professional lobbyists. The addressees of the Code (2) are "all persons appearing on behalf of the organization or representing their interests in relation to the policies, programs or legislative proposals discussed, adopted or implemented by widely understood institutions and public authorities in the Republic of Poland. These organizations include interest groups, government and non-governmental organizations, associations and trade and professional unions, business organizations and industry associations, corporations and advisory and consulting companies." Codes (3), (5) and (8) are addressed to members of relevant associations, code (6) to CLAN and its employees, and the Code (7) is to apply to members of organizations that have adopted the rules proposed by the European Commission. In the following analyses, recipients of all codes are referred to as lobbyists.

A highlighted place in all codes, especially in the preamble, but also in further parts is the reference to values.

The lobbyist-client relationship must be based on candor and mutual respect. (1)

Signatories of this Code commit to comply with its provisions, always acting in a dignified, responsible and reliable manner. (2)

APPC member organisations are determined to act at all times with the highest standards of integrity and in a professional and ethical manner reflecting the principles applied by this Code. (3)

A lobbyist should conduct lobbying activities with honesty and integrity. (4)

European affairs professionals when making representations to the EU institutions shall act with honesty and integrity at all times, conducting their business in a fair and professional manner. (5)

Interest representatives are expected to behave in line with the principles of openness, transparency, honesty and integrity, as expected of them by the citizens in a democratic system. (7)

A commitment to being truthful to clients, political institutions, the media and the public: de'ge'pol members work solely with information that, to the best of their knowledge, reflects the truth. (8)

\section{The axiological basis of the lobbyist's profession}

An overview of all norms in the codes allows for the reconstruction of values to be the axiological basis of the lobbyist's profession. These values are honesty, reliability, integrity, trust, integrality, professionalism, civic responsibility, frankness, 
transparency, openness, clarity, loyalty, respect, kindness. The codes draw attention to the lack of value that could be considered as constituting the profession of a lobbyist, i.e. the value like human life and health is for physicians, truth for scientists, and justice for lawyers.

Some of the codes emphasize that lobbying should sustain and strengthen public trust, as well as create a mentality oriented towards the common good. The last one is clearly emphasized in the code (1, p. 84).

The pursuit of lobbying must take into account the common good, not merely a particular client's interests narrowly considered. Because the purpose of lobbying is to influence the making of public policy, lobbyists should recognize that their responsibilities are different from those of an advocate in a purely private controversy between two adversaries, such as the parties to a lawsuit. By its nature, the lobbying process is designed to influence policymakers whose decisions and choices will have much broader political consequences. Therefore, in deciding whether to undertake an engagement or assignment and in determining what arguments to advance in support of, or in opposition to, a position, lobbyists should weigh the implications of their efforts for the well-being of the country as a whole; and they should inform both their client and the policymaker of the probable economic, social, and political consequences of the policy objectives being pursued The lobbyist should give special attention to the effects of government action or inaction on the least advantaged and most vulnerable citizens. While serving as an advocate for a client's position, the lobbyist retains a personal responsibility as a citizen for the fairness, integrity, and effectiveness of the policymaking process, as well as for the substantive political outcomes to which it leads.

Perhaps civic responsibility understood in this way could play the role of this missing value which is of paramount importance to the profession of a lobbyist.

The codes draw attention to the important place lobbying takes in democratic processes and emphasizes the role that ethical advocacy of interest can play in strengthening democracy. However, in no code can we find an explanation of what this role would be, which, considering the capacity of the concept of democracy, which houses many ideas, leaves these statements at the level of ambiguous slogans.

\section{The normative basis of the ethical codes of the lobbyist}

Analysis of the content of individual norms contained in the codes indicates that they focus on the following issues.

\subsection{Legalism}

A common feature of most codes is the recognition that the law is an ethical minimum. This is manifested in the declaration of legalism, and therefore in compliance with the law in all circumstances. The signatories of the Code (2) commit 
themselves in all undertaken actions to comply strictly with the provisions of law in force in the Republic of Poland. This Code prohibits the use of illegal methods to obtain information from representatives of institutions and public authorities. The Code (4) requires lobbyists to know the law and all regulations related to lobbying, and prohibits not only violation of the law in any form but contributing to the violation of the law by persons holding public functions. The Code (3) prescribes compliance with the regulations of all the parliaments operating in Great Britain, as well as with Nolan's rules of public life.

\subsection{Transparency of action}

The norm in all codes is the order for lobbyists to reveal their own and their organization's identity. It is reprehensible to suppress one's identity, pretend to be someone else, to mislead about the interests that are represented. Some codes contain an order to inform about the represented client and his interest, however, the recipients of this information are not specified.

\subsection{Care for reputation and the dignity of the profession}

The codes recommend avoiding all activities that could negatively affect the image of the profession or degrade its dignity. A lobbyist should be aware that his compliance with ethical standards contributes to creating a positive image of the entire profession and strengthening public trust.

He should treat other lobbyists, including those who work for competitive interests, as well as his colleagues representing the same profession, not hurt their good name and treat everyone with respect. Out of concern for the good name and dignity of the profession, a lobbyist who obtains information that another professional is performing his duties breaking the law, using corruption, violating trade secrets, harming the public good, should report it to the appropriate institutions dealing with such matters.

\subsection{Avoiding corruption}

Most codes prohibit lobbyists from offering and transferring any benefits to representatives of institutions or public authorities, members of parliament, office staff, and families. This applies to direct and indirect benefits, immediate and deferred in time, material and non-material. At the same time, it is prohibited to accept such benefits.

\subsection{Conflict of interest}

Almost all codes contain an order to avoid conflicts of interest. Conflict of interest occurs when a person (or organization) is obliged - as a result of external circumstances or own actions - to double loyalty, that is, he should achieve goals that cannot be achieved at the same time in a certain situation (Lewicka-Strzałecka, 2006). A conflict of interest in the activities of a lobbyist takes place when his 
personal interest is contrary to the interests of the client, or when he also represents clients whose interests are incompatible. Negative effects of conflicts of interest are reduced by avoiding or revealing conflicts and monitoring. Some codes specify conflict of interest situations and recommend appropriate behaviours. According to the Code (2), the conflict of interests consisting in combining professional activity with performing functions in public authorities and institutions should be avoided. A similar recommendation is contained in the Code (8). The code (3) prohibits lobbying companies from employing members of all parliaments and political assemblies operating in the United Kingdom and giving prizes in any form to them or to related persons. Any financial links between lobbyists and decision makers are forbidden. Lobbyists cannot combine the role of advisors of local authorities with services provided to clients with the aim of influencing the decisions of these authorities. Lobbyists must very clearly separate their professional activity from political involvement.

According to the Code (4), lobbyist shouldn't accept or continue orders that lead to a conflict of interest without the client or potential client accepting this situation. He should disclose to the client all potential conflicts of interest and consider possible solutions. If a lobbyist works for a client in a case that can have significant consequences for another client, then even if he does not represent another client in this case, he should inform him about it and get his acceptance for this situation. The lobbyist should inform the client about any paid orders related to the client's case, performed by external entities and about the costs of these orders. Codes (5) and (7) advocate limiting conflicts of interest by recommending that when recruiting former EU officials, they are only those who meet the formal conditions and respect their obligation to comply with applicable rules and confidentiality requirements.

\subsection{Customer relations}

All analyzed codes formulate numerous obligations regarding the behaviour of the lobbyist towards the client. On the one hand, these duties are oriented towards the client's good or interest, and on the other-they point out that this interest cannot be pursued at any price, in violation of the basic principles. Therefore, a lobbyist should only undertake such tasks, entrusted to him by the client who wants to implement those using ethical methods. He should inform his client about the possible negative effects of the goals, tactics and strategies that are being considered. This applies not only to the consequences for the client's interest and reputation but also for the common good and other groups of citizens, especially the poor and those who don't have their representation. The lobbyist should clearly inform what actions may be illegal, immoral or unprofessional and do not undertake to perform them.

When trying to get a job, a lobbyist should not overstate his skills, previous experience and potential contacts. If he doesn't have sufficient resources or appropriate political contacts to represent the client, he should inform him about it. He should also inform him about all previous efforts that were made in a given case. 
A lobbyist should try to represent his client's interests in a competent and professional manner. The condition for this is excellent knowledge of legislative processes, political orientation and specialist knowledge that should be improved through systematic education, participation in training, seminars and sessions.

All information provided to customers must be reliable and accurate. The lobbyist should loyally, conscientiously and diligently act in the interests of his client, devoting a sufficient amount of time, attention and resources to it. He should systematically and thoroughly inform the client about the progress of the task and give him the opportunity to choose between different options and strategies.

An important requirement is a prohibition of disclosure of the client's confidential information without their consent. The lobbyist should not use the client's internal information to act against him or for any other purpose not mentioned in the contract between them.

The Code (4) recommends the conclusion of a written agreement between the lobbyist and the client, which will specify all terms and conditions of order execution as well as the amount and rules of remuneration.

In its code, CLAN sets norms (6) for relations with customers in even more detail. It commits to providing "tailored" services that is adapted to the individual requirements and parameters of the client. Analyses made for a large corporation will be completely different from those that were commissioned by a medium or small company. CLAN does not discriminate against any client, but if it is aware that it cannot help him, it does not accept the order. CLAN clearly defines the rules of payment: it can be a fixed remuneration, pay per hour, or dependent on the achieved results. Customers have access to the company's work schedules.

Exceptionally, in one of the analyzed codes (1), there was also a standard addressed to the client saying that the client who is considering the involvement of a particular lobbyist should take into account his ethical image. Knowing that there are some reservations about the ethical side of the work of a lobbyist or company, the client should not engage them without clarifying these reservations.

\subsection{Relations with decision-makers and public institutions}

The goal of lobbyists' contacts with public officials is to influence their decisions, but at the same time, ethically responsible lobbying should play important educational and social functions, because honest, well-informed lobbyists provide decision-makers with important information and arguments that can be decisive in public debate. Most of the codes emphasize that the decision-maker has the right to expect the lobbyist to disclose accurate and reliable information about the client's identity, the nature and consequences of the goals he wants to achieve. The information provided should always be truthful, up to date and accurate. A lobbyist shouldn't deliberately mislead anyone. He should not skip or conceal any information that is important for making a decision. According to the Code (4), if the lobbyist gains knowledge that the information he has given to the decisionmakers is inaccurate or untrue, he should inform them as soon as possible and do 
everything to provide reliable and accurate information. He should behave similarly if it turns out that the information provided, on the basis of which public decisions are made, ceases to be current.

If the lobbyist knows about the risks associated with the solution he has been advocating and realizes that the decision-maker will not be informed about it by anyone, then the Code (1) puts him under strong pressure to do so. The Code also contains a norm stating that the strategy of exerting influence on a decision-maker cannot be based on attempts to deprive it of its independence, such as suggestions regarding possible support for an election campaign or influencing the deterioration of his public image.

The Code (4) emphasizes the duty of a lobbyist to act in a way that does not undermine trust in the public sphere and the belief that power is being exercised in a democratic manner. A lobbyist should not show disrespect for public institutions.

A common norm is the obligation to comply with the rules and regulations defining the principles for obtaining and disseminating parliamentary and governmental documents. Formulated in the Code (2) the obligation to "not sell copies of documents obtained from representatives of institutions and public authorities for profit to third parties," is in an appropriate form also in other codes. The Code (3) formulates in some detail the rules for using access passes for government buildings to prevent the use of passes obtained for a specific purpose for other purposes.

Codes require lobbyists to comply with the rules and internal regulations of public institutions with which they cooperate in any way. It is forbidden to use employees employed in these institutions and their technical infrastructure for their own purposes. The codes also indicate the ban to persuade politicians and public officials to violate the rules and standards that apply to them.

\subsection{Obligations to society}

A fairly common social misunderstanding of the essence of lobbying puts a special educational mission on lobbyists. It consists of raising awareness of the public role of lobbying in a democratic society and promoting behaviour that strengthens trust in this activity. At the same time, a lobbyist who performs an extremely important role in making political decisions should inform and educate both his clients and decision-makers.

According to the Code (7), lobbyists should ensure, in accordance with their best knowledge, that the information they provide is objective, complete, current and not misleading. According to the Code (1), it is reprehensible to create campaigns aimed at distracting public attention from its actual goals and directing interest towards phantom or substitute phenomena. 


\subsection{Relations with entities shaping public opinion}

Influencing decisions taken in government institutions by influencing public opinion is acceptable in lobbying activities but must be subject to certain rules. The principles of media campaigns must be clearly defined, their goals and potential benefits must be clear. All information provided to the media must be true and accurate, not misleading or concealing relevant information. The lobbyist should keep the confidential information about his client secret, but it is reprehensible according to the code (1) to manipulate or counteract the efforts of journalists trying to reach information that is crucial for decisions in the public sphere, and to want to present them objectively and genuinely. In the creation of media campaigns, it is reprehensible to use strategies oriented towards making decisions in the public sphere which bring unfair benefits to clients commissioning these campaigns. These are campaigns that do not reveal the real goals they serve, which are a form of hidden advertising, manipulating people's emotions, opinions and views, engaging huge financial resources, disturbing the balance on the media market. A lobbyist who pursues his client's goals should equally respect the rights of citizens and public officials to reliable and true information.

The comparison of norms contained in individual codes shows that there are no conflicting norms, despite the fact that the codes represent different lobbying cultures. It can be assumed that this results from the aforementioned high level of generality of standards, because an attempt to interpret them in specific situations may lead to different solutions. For example, the concept of improper influence, the exertion of which on EU officials is prohibited by the norm contained in the Code (5), is understood by the authors of this Code as "something given with the intention of causing the recipient to act in a way that they would not have done without the inducement." It can be presumed that if the impact isn't created with such intention, the impact is not inappropriate, i.e. inviting a member of the European Parliament to a dinner may be (and often is) regarded as a normal business. Meanwhile, according to the American Code (4) requiring fair treatment of decision-makers and respect of the law, payment by the lobbyist for the congressman's dinner is unacceptable regardless of the intent of the one inviting.

The highest risk of conflict between standards occurs in the case of a norm that requires informing about the represented client and his interest, and a norm that requires respect for the client's secret. If lobbying means influencing the decision-making process undertaken by the authorities, then the first norm results from the right to public information. The second standard results from a contract concluded between a lobbyist and a client who entrusts their secrets in the belief that they will not be revealed. The codes do not show any direction of settling the conflict between the transparency of lobbying and the protection of privacy or commercial secrecy of the client. 


\section{Enforcement of codes}

As mentioned earlier, codes of conduct are a very important, but not an integral element of the self-regulation of the environment. Efficient self-regulation also requires the implementation of a system that ensures compliance with the principles contained in the code. An analysis of such a system in relation to the above codes leads to the following conclusions. The Code (1) is only a draft of certain rules and does not provide for sanctioning at all. Acceptance of the Code (2) is a prerequisite for joining the Professional Lobbyist Association in Poland. The non-compliance of a member of the Association with the principles contained in the Code (2) may be a reason to exclude him from the organization, and in the event of breaking any provisions of the Code, a member of the Association commits to voluntarily relinquish membership of the Association. However, there is no provision for an institution that has to adjudicate that the standards contained in the Code have been violated. In turn, APPC established a very extensive and accurate procedure for handling complaints about breaking the rules contained in the code (3). This multistage procedure for examining any breach is to guarantee the reliability of the services provided, ensure customer satisfaction and safeguard the reputation of lobbyists. The examination will be dealt with by a special committee, the possibility of mediation and appeal is envisaged. It turns out that this system does not fulfil its function because it has never been used. Acceptance of the Code (4) is a condition of joining the American League of Lobbyists. The offer of the League includes obtaining a certificate of a professional lobbyist based on training, among which training in the field of lobbying ethics providing knowledge about the interpretation of the principles contained in the code is obligatory.

The lack of a system for sanctioning the rules contained in the Code (5) was most often the reason for its criticism, so the SEAP association modified its code and established a procedure for reporting violations of its principles. Sanctions start with a written warning and end with removal from the association. Each member of the association, along with joining it must commit himself to comply with the rules contained in the code and participate in a seminar on the content of these principles. During this 90-minute seminar, it explains how rules should be interpreted in practical situations and what procedures will be implemented in the case of a violation of the rules. At the end of the seminar, each participant receives a certificate that he is a full member of the SEAP. The Code (6) does not provide for any means of sanctioning the standards it contains, but since CLAN has also committed to complying with the SEAP Association Code (5), it can be assumed that it also accepts its enforcement system. Acceptance of the Code (7) is a condition for submitting to a voluntary register for representatives of interest groups established by the European Commission, but there is no system sanctioning compliance with the standards contained therein. Persons applying for admission to the German association of consultants operating in the policy area must pledge to comply with the principles contained in the Code (8) and are also informed about the types of penalties for violating these principles. 
The analysis of the above examples of the self-regulation of lobbying indicates that the weak link of these self-regulations is the systems of enforcing the norms contained in the codes. Most of these codes are only declarative and there are no procedures for their implementation. In two cases, the association of lobbyists enables training on the interpretation of the principles contained in the code. However, there are usually no procedures for reporting violations, no sanctions system, and where such a system has been established, it is not used.

\section{Conclusion}

The analysis conducted on ethical codes regulating lobbying activities leads to the following conclusions.

The axiological basis of the lobbyist's profession is formed by the following values: honesty, reliability, integrity, trust, integrality, professionalism, civic responsibility, frankness, transparency, openness, clarity, loyalty, respect, kindness.

The standards contained in the lobbying codes focus on the following issues: legalism, transparency of action, concern for the reputation and dignity of the profession, avoidance of corruption, conflict of interest, relations with clients, relations with decision-makers and public institutions, obligations to society, relations with entities shaping public opinion.

A weak link in the self-regulation of lobbying is the enforcement of norms contained in the codes.

\section{References}

American League of Lobbyists Code of Ethics. (2010). doa.alaska.gov/apoc/pdf/Lobbyist CodeOfEthics.pdf

APPC Code of Conduct. https://www.appc.org.uk/code-of-conduct/appc-code-of-conduct/

CLAN Public Affairs Code of Conduct. http://clanpa.eu/

The Ethics of Lobbying: Organized Interests, Political Power, and the Common Good. (2002). Washington D.C.: The Woodstock Theological Center, Georgetown University Press.

European Commission Code of Conduct for Interest Representatives. http://ec.eu ropa.eu/ transparencyregister/public/staticPage/displayStaticPage.do?locale $=$ en\&reference $=$ CODE_OF_CONDUCT

German Association of Political Consultants Code of Conduct. https://www.degepol.de/ code-of-conduct

Jasiecki, K., Molęda-Zdziech, M., \& Kurczewska, U. (2006). Lobbing. Sztuka skutecznego wywierania wplywu. Kraków: Oficyna Ekonomiczna.

Lewicka-Strzałecka, A. (2006). Odpowiedzialność moralna $w$ życiu gospodarczym. Warszawa: Wydawnictwo Instytutu Filozofii i Socjologii Polskiej Akademii Nauk. 
Lewicka-Strzałecka, A. (2012). Etyczny wzór lobbingu: analiza kodeksów regulujących działalność lobbingową. Annales. Ethics in Economic Life, 15, 109-119.

Society of European Affairs Professionals. (1997). Code of Conduct. https://www.eesc.eu ropa.eu/.../118-sg-seap-code-of-conduct.pdf 